\title{
КОМБИНОВАЊЕ ТРАДИЦИОНАЛНИХ И ДИГИТАЛНИХ МЕДИЈА У СВРХУ БОЉЕ ПРЕЗЕНТАЦИЈЕ КУЛТУРНОГ ТУРИЗМА У СРБИЈИ
}

\author{
Зоран Радосављевић¹, Тијана Љубисављевић²
}

\begin{abstract}
Сажетак
Културни туризам је набрже растућа туристичка грана. Према истраживању UNWTO, 40\% свих интернационалних путовања чине «културни туристи», односно 530 милиона у 2017. години. Број културних туриста сваке године расте, а туристи су све млађи. Културно и историјско наслеђе привлачи све већи број посетилаца. Музеји, археолошка налазишта, манастири, стара градска језгра су интересантни различитим групама туриста. Демографске одлике указују на потребу за различитим приступом, како на самом локалитету, тако и у примени различитих медија која се користе за њихово привлачење. Различити узрасти, пол, образовање, итд., прате различите медије, од традиционалних до дигиталних. Коришћењем више средстава комуникације, ствара се микс који различито презентује одређену културну дестинацију, различитим демографским групама (варијабле: старост, пол, образовање, националност,...). Све већа заступљеност рачунара у домаћинствима у Србији, чини приступачност дигиталнијим медијима већом. Ипак, још увек статистички значајан удео становништва информације прикупља из традиционалних медија. Поверење је и даље на њиховој страни.

Овај рад ће се бавити начинима комбиновања различитих медија у сврху повећања заинтересованости културних туриста у Србији.
\end{abstract}

Кључне речи: културни туризам, дигитални медији, традиционални медији.

\footnotetext{
Универзитет у Крагујевцу, Факултет за хотелијерство и туризам, Врњачка Бања. e-mail: zoran.rad@mts.rs

2 Универзитет у Крагујевцу, Факултет за хотелијерство и туризам, Врњачка Бања. e-mail: t.ljubisavljevic@gmail.com
} 


\title{
COMBINING TRADITIONAL AND DIGITAL MEDIA FOR THE PURPOSE OF BETTER PRESENTATION OF CULTURAL TOURISM IN SERBIA
}

\begin{abstract}
Cultural tourism is the fastest growing tourist branch. According to UNWTO research, $40 \%$ of all international travels are "cultural tourists", about 530 million in 2017. The number of cultural tourists is growing every year, and tourists are getting younger. Cultural and historical heritage attracts an increasing number of visitors. Museums, archeological sites, monasteries, old towns are interesting to different groups of tourists. Demographic characteristics indicate the need for a different approach, both on the site and in the application of different media used to attract tourists. Different ages, gender, education, etc., follow different media, from traditional to digital. By using different means of communication, a mix is created that presents a certain cultural destination differently, to different demographic groups (variables: age, gender, education, nationality,...). The increasing presence of computers in households in Serbia makes the accessibility of digital media larger. However, a large percentage of the population still gathers information from traditional media. Trust is still on their side.

This paper will deal with ways of combining different media in order to increase the interest of cultural tourists for Serbia.
\end{abstract}

Keywords: cultural tourism, digital media, traditional media.

\section{УВОД}

Установе културе у Србији, у које се сврставају музеји, галерије и задужбине, после кризе средином деценије, бележе све више посета. Према подацима Завода за проучавање културног развитка, број посета музејима је, после пада у периоду од 2012 до 2015. године, почео да расте. Број музеја који је био доступан посетиоцима 2012. године био 104, а те године регистровано је укупно 2.992.000 посета, док је у 2015. години радило 140 музеја, а број посета је износио 1.887.000. У 2018. години се види напередак и у броју музеја и броју посетилаца: број музеја који раде је 149, а забележено је 2.272.000 посета.

Према истраживањима које је 2009. године урадила Драгана Мартиновић (2010) за подручје Републике Србије, уочавају се три групе посетилаца са 
сличним процентом учешћа у укупном броју посетилаца. То су групе од 1318 година, 19-26 година и група од 36-50 година. Оне учествују са по 20\%. Овде треба истаћи да број млађих посетилаца од 13-18 година чине ученици који посећују установе културе према школском плану и програму за екскурзија. Остале групе, информације о културним дешавањима добијају из различитих медија. Повећањем старосне доби, опада коришћење интернета, а расте гледаност и слушаност традиционалних медија. Велики утицај на одабир медија има стручна спрема. Коришћење традиционалних медија је карактеристично за особе са средњим и нижим образовање, док порастом стручне спреме, расте и време проведено на дигиталним медијима.

Страни туристи који посећују Србију, према анкети Туристичке организације Србије (TOC, Propozitiv, 2016), за разлог доласка наводе упознавање са културним и историјским наслеђем (62,4\%). Старост туриста који долазе у Србију се у претходним годинама променила. Данас су то све више млади и образовани, који користе дигиталне медије.

Циљ истраживања овога рада јесте утврђивање оптималног утицаја на туристе базираног на комбинацији традиционалних и дигиталних медија на одређене демографске групе, приликом доношења одлуке о посети одређеној културној дестинацији или културном догађају.

Научни циљ тежи доказивању потребе за различитим комбинацијама традиционалних и дигиталних медија у процесу доношења одлуке о избору културне дестинације или културних догађаја одређених демографских група.

Друштвени циљ је повећање видљивости културног наслеђа код различитих туристичких група.

Хипотеза: Комбиновање више различитих медија, који се користе за промоцију културне баштине, допире до већег броја туриста.

\section{КУЛТУРНИ ТУРИЗАМ}

Култура и туризам су одувек нераскидиво повезани. Културне знаменитости, атракције и догађаји представљају важну мотивацију за путовања, а сама путовања стварају културу. Али тек последњих деценија веза између културе и туризма је идентификована као специфичан облик потрошње: културни туризам (Richards, 2018). Појава културног туризма као друштвеног феномена и као предмета академског проучавања може се пратити од пораста слободних путовања после Другог светског рата. Путовања су у 
Европи помогла да се повећа културно разумевање и обнове разорене економије.

Почетак деведесетих указује на период трансформације културног туризма који је, за разлику од изворне оријентације према елитној клијентели, пронашао нову прилику за развој у оријентацији према масовном тржишту. Културни туризам постао је добро утврђен феномен на многим туристичким дестинацијама и све је више мета академског истраживања. Раст културног туризма обележен је и фрагментацијом у бројне настајуће нише, као што су туризам културне баштине, уметнички туризам, гастрономски туризам, филмски туризам и креативни туризам (Richards, 2001). Раст је донео и властите изазове, а до 2013. године Бонифаце је већ сигнализирао проблеме са пренатрпаности понудом културнебаштине (Boniface, 2013). Извор тешкоћа са којима се сусрећу чувари опипљиве баштине је у све већој жељи туриста за новим искуствима. Пажња се усмерава на улогу нематеријалне баштине у туризму (Du Cros, 2012). Промењиву природу културног туризма недавно је довео у фокус извештај UNWTO-а о синергији туризма и културе (2018), који је обухватио онлајн анкете које покривају 43\% држава чланица UNWTO-а, као и 61 међународног стручњака у тој области. Ова студија потврдила је значај културног туризма, при чему је 89\% националних туристичких управа показало да је културни туризам део њихове туристичке политике. Испитаници су такође навели да очекују даљи раст културног туризма у наредних пет година (UNWTO, 2018).

Културни туризам је добио нову оперативну дефиницију UNWTO-а на 22. заседању Генералне скупштине одржане у Кини (UNWTO, 2017): Културни туризам је врста туристичке активности у којој је суштинска мотивација посетиоца да у туристичкој дестинацији научи, открије, искуси и конзумира опипљиве и нематеријалне културне атракције/производе. Ове атракције/производи односе се на скуп карактеристичних материјалних, интелектуалних, духовних и емоционалних карактеристика друштва које обухвата уметност и архитектуру, историјску и културну баштину, кулинарску баштину, књижевност, музику, креативне индустрије и живе културе својим животним стиловима, вредностима системима, веровањима и традицијама (UNWTO, 2017).

Према анкети Туристичке организације Србије (ТОС, Propozitiv, 2016), страни туристи за разлог доласка наводе упознавање са културним и историјским наслеђем 62,4\%. Профил туристе који долази у Србију је мушкарац (60,5\%), старости између 18-29 година (38,8\%), високог или вишег образовања $(66,4 \%)$, који се информише о дестинацији користећи Интернет (63,9\%). Традиционалне медије, за информисање, користило је 14,3\%. 
Чувари дела културне баштине су музеји. Међународни савет музеја (ICOM) дефинише музеј као непрофитабилну, сталну институцију у служби друштва и отворен је за јавност, која стиче, чува, проучава, излаже и шири опипљиво и нематеријално наслеђе човечанства ради проучавања, сврхе образовања и рекреације (ICOM, 2007). Музеј своју мисију преноси на више начина, наиме истраживачким алатима, образовним активностима, организацијом изложбених простора и употребом најсавременијих информационих и комуникационих технологија (van Hooff, 2012).

\section{ТРАДИЦИОНАЛНИ И ДИГИТАЛНИ МЕДИЈИ}

Традиционални медији спадају у врсту масовне комуникације. Медији масовне комуникације или мас - медији као појам улазе у употребу двадесетих година прошлог века, појавом радија и телевизије. Они се разликују од других видова комуникација по следећим критеријумима:

- поруке су усмерене на већи део популације;

- у трансмисији се користе техничка средства;

- поруке се истовремено преносе масовној публици (Filipović, KostićStanković, 2008).

У традиционалне медије, који су носиоци настанка појма медија масовних комуникација, спадају штампа, фотографија, филм, радио и телевизија. Ови медији као основну карактеристику имају слање порука у једном смеру.

Тек појавом нових или дигиталних медија долази до заокруживања комплетних медија масовне комуникације. Дигитални медији у које спадају Интернет и мобилни медији имају могућност двосмерне комуникације. Они повратну информацију добијају од корисника готово моментално, за разлику од традиционалних који често повратну информацију добијају преко анкета, друштвених дешавања, али и повећања броја посета одређеним догађајима или дестинацијама. Један од начина јесте и повећан број претрага појмова везаних за дестинацију и резервисања ноћења преко Интернета. Овде се већ уочава потреба коришћења традиционалних и дигиталних медија. Такође, традиционални медији све чешће користе платформе дигиталних медија за дистрибуцију и емитовање свог програма. Више не можемо да говоримо о скупу различитих медија, већ о њиховом комбиновању.

Иако су традиционални медији доживели ренесансу појавом дигиталних медија, јер се користе њиховим платформама за дистрибуцију свог програма, телевизија највише користи потенцијале нових медија, пласирајући своје 
програме преко различитих Интернет портала. Телевизија на Интернету више нема стандардну програмску шему, већ сам корисник бира шта ће да гледа. Такође, има могућност остављања коментара испод сваког одгледаног програма. Тако телевизија, од стандардног традиционалног медија који информације шаље у једном смеру, постаје двосмерна користећи дигиталне платформе.

Одређене програме на дигиталним медијима конзумирају одређене групе. Употребом друштвених медија, сам медији постаје једнак члан те заједничке групе која се може дефинисати према географским, демографским и психографским сегментима.

Стокер, Комфорт и Грин су развили модел алгоритма који показује да дигитални медији који се налазе унутар групе, као њихов равноправни члан, могу да развију социјалну мрежу у којој могу да изграде заједнички став (а), док на другој страни телевизија као традиционални једносмерни медији утиче на поједине чланове, разграђујући групу (6). ( Stocker et al, 2003)

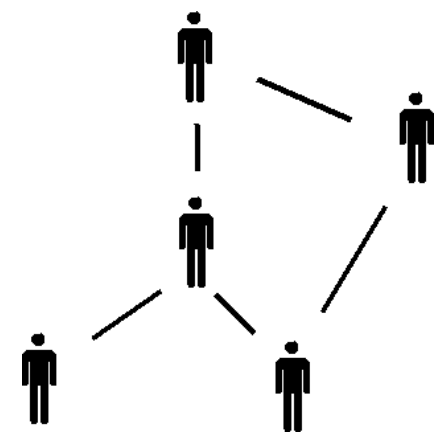

(a)

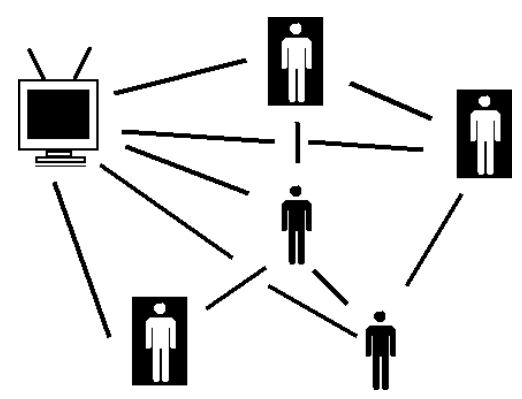

(b)

Извор: R. Stocker, D. Cornforth, and D. G. Green (2003) The impact of television on cohesion in social networks - a simulation study 
Ипак, телевизија мора да се посматра на оба начина. Наиме, истраживање које су урадиле Богдана Опачић и Бојана Субашић (2016) за потребе Завода за проучавање културног развитка, показује да 49,2\% становништва Србије своје слободно време проводи гледајући телевизију, читајући новине и слушајући музику. Тај проценат прелази $62 \%$ код доби старијој од 50 година. То је један од разлога што се број телевизијских станица у Србији не смањује. Према подацима Републичког завода за статистику, број телевизијских станица је од 2010. године, када их је било 95, порастао на 118 у 2018. години (РС3, 2019).

Један од показатеља да је интересовање за традиционалне медије и даље велико јесте истраживање IPSOS-а спроведено у новембру и децембру 2019 године. На питање „Којим путем се све информишете о текућим политичким, друштвеним и другим темама из земље и света", $82 \%$ испитаника је одговорило да је телевизија начин њиховог информисања, док 46\% да су то дигитални медији. Значи, део испитаника користи оба медија. Међутим, на исто питање, $88 \%$ у популацији од 18 до 29 година одговорило је да се информише преко дигиталних медија, а 58\% да им је телевизија извор информација.Упопулацији са више од 60 година највише је оних који информације прикупљају гледајући телевизију - 96\%, а значајно мање преко дигиталних медија - 7\% . Дакле, може се констатовати да је утицај телевизије и даље доминантан.

\section{ПОТРЕБА ЗА КОМБИНОВАЊЕМ МЕДИЈА У ЦИЉУ ПРОМОЦИЈЕ КУЛТУРНОГ ТУРИЗМА}

Појава и развој Интернета заначајно је променила начине маркетиншког комуницирања између организација, у овом случају установа културе, и крајњег корисника. Традиционални медији се користе превасходно за оглашавање. Комуницирање је једносмерно, а резултати нису директно мерљиви. Међутим, не треба занемарити чињеницу да је овај вид комуникацијеса потенцијалномпубликом идаљенајвише коришћен (Radosavljević, Ljubisavljević, 2019). Разлог је што телевизија држи примат над осталим медијима. Проблем оглашавања на традиционалним медијима, нарочито телевизији, представља висока цена, а поруке не могу у довољној мери да стижу до жељених циљних група.

Развојем Интернета дошло је до промене начина комуницирања. Од једносмерне, организација-корисник, постала је двосмерна и то у три правца: један према један, један према многима и многи према многима (Jensen, 2010). 
Овакав начин комуницирања довео је до промене и у самом концепту интегрисане маркетиншке комуникације. Интернет, заједно са другим дигиталним алатима (друштвене мреже, мобилне апликације, видео игре и др.) није само инструмент за оглашавање, већ се користи и за директни маркетинг, унапређење продаје, па чак и неких облика личне продаје. Продаја робе, улазница за културна дешавања, туристичких аранжмана преко Интернета, померила је трговину са конвенционалног начина на нове платформе, које су у сталном развоју (Radosavljević, Ljubisavljević, 2019).

Варадајан и Јадав (Varadajan, Yadav, 2009) објашњавају потребу да се досадашњи маркетинг ресурси комбинују са новим Интернет технологијама, при доношењу одлука о прављењу маркетиншке стратегије.

Описне одлуке маркетиншке стратегије, које подразумевају повећање постојеће стратегије, у различитом степену, од стране потенцијала Интернета су следеће:

1. Релативно истицање традиционалних приступа насупрот Интернет приступу, како би купци добили информације у вези са производом, да би им исти био представљен и продат, али зарад комуникације са купцима;

2. Релативно истицање директног маркетинга са купцима путем Интернета, насупрот посредницима;

3. Коришћење потенцијала Интернета за иновирање, прилагођавање и персонализацијуудоменупроизвода, цене, промоције, дистрибуције и управљања односима са клијентима (нпр. иновација производа, прилагођавање производа и персонализација производа (Varadajan, Yadav, 2009).

\section{МЕТОДОЛОГИЈА}

Метода која је коришћена у овом раду је упоредна. У раду су упоређују различити демографски подаци из истраживања које су спровели екстерни истраживачи, а ради добијања адекватне комбинације традиционалних и дигиталних медија за бољу промоцију културног туризма. Истраживања су спроведена у сличном периоду и односе се на коришћење различитих врста медија, броја посета музејима, културним потребама и навикама грађана и др. 


\section{РЕЗУЛТАТИ ИСТРАЖИВАЊА}

Просечна старост становника Србије је 43,3\% (РС3, 2011). Слободно време проводи гледајући телевизију и читајући новине више од 40\%, док њих око 28\% трага за подацима на Интернет, а тек око 5\% посећује културна дешавања.

Млађа популација своје слободно време подједнако проводи користећи дигиталне и традиционалне медије (око 38\%), док је посета културним догађајима нешто изнад просека опште популације, с обзиром на то да млађа популација, у оквиру наставних активности обилази музеје и остале културне и историјске поставке (9,3\%). Треба истаћи да у дигиталне медије спадају и видео игре, које млађа пунолетна популација игра тзв. озбиљне видео игре $(56,7 \%)$, у којима је сужен простор за комуникацију са корисницима (Radosavljević, Ljubisavljević, 2019).

Старије становништво у Србији, слободно време проводи углавном уз традиционалне медије - око 63\%, дигиталне - око 15\%, а тек 5\% посећује културне догађаје.

Да би се културни туризам презентовао у Србији и даље су неизоставни традиционални медији. У зависности од демографске кохорте, мења се и однос између традиционалних и дигиталниг медија. Наравно, ово је полазна тачка, а у зависности од циљне групе и маркетиншке стратегије, коришћење медија трпи корекције.

Страни туристи који су посетили нашу земљу, углавном су у трећој деценији и четвртој деценији (око 64\%), високог образовања (око 66\%), који посећују културно наслеђе Србије (око 63\%). За проналажење информација о дестинацији њих 64\% користили су Интернет, а традиционалне медије око $15 \%$. Ови показатељи говоре да је за повећање заинтересованости страних туриста за Србију, кључно презентовање на дигиталним медијима.

\section{ЗАКЉУЧАК}

Овај рад је показао да је потребно истовремено комбиновати традиционалне и дигиталне медије у процесу промоције културног наслеђа. На тај начин је потврђена хипотеза да се комбинацијом више различитих медија, који се користе за промоцију културне баштине, допире до већег броја туриста. Туристи из Србије и даље доминантно користе традиционалне 
медије да би се упознали са жељеном дестинацијом, док страни туристи знатно више информација прикупљају из дигиталних медија.

Рад може да представља оквир и полазну тачка за будућа истраживања. Даља истраживања би требала да буду усмерена у правцу развијања маркетиншких стратегија за појединачне циљне групе.

\section{ЛИТЕРАТУРА}

1. Boniface, P. (2013). Managing Quality Cultural Tourism. London: Routledge.

2. Van Herman, V.H. (2012). Contribution of Museums to Development, Culture and Development, UNESCO Cuba

3. Varadarajan R., Yadav, M.S. (2009). Marketing Strategy in an Internet-Enabled Environment: A Retrospective on the First Ten Years of JIM and a Prospective on the Next Ten Years, Journal of Interactive Marketing 23 , pp 11-22

4. Du Cros H. (2012). Intangible cultural heritage, education and museums, UNESCO Arts in Education Observatory for Research in Local Cultures and Creativity in Education

5. Ipsos (2020). Toliko toga nas spaja - Medijska slika regiona.

6. https://www.ipsos.com/sr-rs/toliko-toga-nas-spaja-medijska-slika-regiona Приступљено: 18.08.2020.

7. ICOM. (2007). RESOLUTIONS ADOPTED BY ICOM'S 22ND GENERAL ASSEMBLY, Vienna, Austria

8. Jensen, K. B. (2010). Media Convergence: The Three Degrees of Network, Mass, and Interpersonal Communication. London, New York: Routledge

9. Martinović, D. (2010). Muzejska publika u Srbiji, Analiza istraživanja, Zavod za proučavanje kulturnog razvitka, Beograd

10. Опачић, Б., Субашић, Б. (2016). Културне потребе и навике грађана Србије, Завод за проучавање културног развитка, Београд.

11. Radosavljević, Z., Ljubisavljević, T. (2019). DIGITIZATION OF CULTURAL HERITAGE AS A POTENTIAL FOR INCREASING MUSEUM ATTENDANCE IN CENTRAL SERBIA, Bizinfo, Vol. 10, DOI: 10.5937/bizinfo1901053R

12. Републички завод за статистику: Број кућних прикључака у 2019. години https:// data.stat.gov.rs/Home/Result/270101?languageCode=sr-Cyrl, Приступљено: 20.8.2020.

13. Републички завод за статистику: Процене становништва https://www.stat.gov.rs/ sr-cyrl/oblasti/stanovnistvo/procene-stanovnistva/ Приступљено: 21.08.2020. 
14. Републички завод за статистику: Отворени подаци

15. http://opendata.stat.gov.rs/odata/ Приступљено: 16.08.2020.

16. Richards, G. (2001). Cultural Attractions and European Tourism, Wallingford: CABI.

17. Richards, G. (2018) Cultural Tourism: A review of recent research and trends, Journal of Hospitality and Tourism Management, Volume 36, Pages 12-21

18. Stocker, R., Cornforth, D. and Green D. G. (2003). The impact of television on cohesion in social networks - a simulation study, Complex Systems Group and School of Environmental and Information Science, Charles Sturt University, PO Box 789, Albury NSW 2640 AUSTRALIA, p. 2

19. Turistička organizcija Srbije (2017). Rezultati istraživanja stavova i ponašanja stranih turista u Srbiji u 2016. godini.

20. http://www.tos.rs/aktuelno.2177.html Приступљено: 18.08.2020.

21. UNWTO. (2017). Definitions Committee on Tourism and Competitiveness (CTC). http://cf.cdn.unwto.org/sites/all/files/docpdf/ctcdefinitionsenweb.pdf Приступљено: 25.08.2020.

22. UNWTO. (2018). Report on Tourism and Culture Synergies. Madrid: UNWTO.

23. Filipović, V., Kostić-Stanković, M. (2008). Odnosi s javnošću, Beograd: Fakultet organizacionih nauka

Рад је примљен: 25. август 2020. Прихваћен за објављивање: 31. август 2020.

Received: August 25, 2020.

Accepted: August 31, 2020. 